\title{
KDE KONČÍ MINULOST A ZAČÍNÁ SOUČASNOST? K pojetí lidských práv u Rainera Forsta
}

Rainer Forst (1964) je považován za jednoho z nejvýznamnějších politických filosofů současnosti. Ve svém myšlení úzce navazuje na dílo Jürgena Habermase a Johna Rawlse: v návaznosti na Rawlse vymezuje základní otázku, v návaznosti na Habermase a tradici frankfurtské školy pak základní metodu politické filosofie. Již ve své disertační práci, která vznikala pod přímým Habermasovým a Rawlsovým vedením a která byla $\mathrm{v}$ přepracované podobě publikována pod názvem Kontexte der Gerechtigkeit (1994), Forst obhajoval názor, že základní otázkou politické filosofie je otázka spravedlnosti a její základní metodou metoda diskursivní analýzy. Tento názor Forst zastává a rozvíjí ve svých pozdějších pracích Toleranz im Konflikt (2003), Das Recht auf Rechtfertigung (2007), Kritik der Rechtfertigungsverhältnisse (2011) a Normativität und Macht (2015), které mu zajistily trvalou pozornost a uznání odborné i laické veřejnosti.

O tom, jakou pozornost a uznání si Forstovo myšlení a dílo v poslední době získává, svědčí narůstající počet článků a studií, které jsou mu věnovány. ${ }^{1}$ Pozornost je věnována jak Forstově politické filosofii jako celku, tak jednotlivým jejím motivům a tématům. Jedním z těchto motivů je téma lidských práv. V roce 2016 se proto v nizozemském Tilburgu konala konference, kterou uspořádal Verening voor Wijsbegeerte van het Recht (The Netherlands Association for Philosophy of Law) a která byla věnována právě Forstově pojetí lidských práv. Forst se této konference sám účastnil a vystoupil zde s příspěvkem, ve kterém své pojetí lidských práv shrnul a předložil k diskusi. Na program tilburgské konference pak navázalo zvláštní mezinárodní číslo nizozemského časopisu pro politickou a právní filosofii Netherlands Journal of Legal Philosophy z téhož

1 Viz např. A. Ellen - E. Mendieta (vyd.), Justification and Emancipation. The Critical Theory of Rainer Forst, Pennsylvania 2019; E. Herlin-Karnell - M. Klatt E. H. Morales Zúñiga (vyd.), Constitutionalism Justified. Rainer Forst in Discours, Oxford 2019; M. Haugaard - M. Kettner (vyd.), Theorizing Noumenal Power. Rainer Forst and his Critics, London 2020 aj. 
roku, které přinášelo jak text Forstova vlastního příspěvku s názvem The Justification of Basic Rights. A Discourse-Theoretical Approach, tak kritické reakce na něj.2

Uvedený Forstův text, který je nyní k dispozici také v českém překladu, se týká jednoho dílčího motivu jeho politické filosofie, problematiky lidských práv. ${ }^{3}$ Týká se ale také jejího nejobecnějšího a základního motivu, problematiky spravedlnosti. Otázku lidských práv Forst řeší v souvislosti s problémem spravedlnosti, který chápe jako problém ospravedlnění obecně platných a závazných norem lidského jednání. Přestože se ospravedlnění těchto norem fakticky uskutečňuje prostřednictvím důvodů, nelze je prostě ztotožnit se zdůvodněním. Forst totiž rozlišuje mezi „racionálním zdůvodněním“ (rationale Begründung) a „rozumovým ospravedlněním“ (vernunftige Rechtfertigung). ${ }^{4} \mathrm{~V}$ obou případech se jedná o odpověd’ na otázku „Co mám konat?“, otázka sama, a tedy i odpověd’ na ni, se pokaždé týká něčeho jiného: v případě racionálního zdůvodnění se týká prostředků $\mathrm{k}$ dosažení stanovených cílů, v případě rozumového ospravedlnění se týká obecně platných a závazných norem lidského jednání. Rozumové ospravedlnění se proto od racionálního zdůvodnění odlišuje tím, že se uskutečňuje ve sdíleném prostoru normativity. Důvody, kterými lidé své jednání ospravedlňují, jsou tedy normativní, a jejich platnost musí proto vždy posoudit druzí, zatímco důvody, kterými je zdůvodňují, jsou normativně neutrální, a jejich platnost proto může každý posoudit sám. ${ }^{5}$ Rozumové ospravedlnění tak na rozdíl od racionálního zdůvodnění předpokládá a vyžaduje dialog a diskusi s druhými lidmi. Kritéria pro posouzení důvodů, které lidé v dialogu a diskusi s druhými uvádějí, aby s jejich pomocí ospravedlnili určité jednání, jsou podle Forsta dvě: reciprocita (Reziprozität) a všeobecnost (Allgemeinheit). Podaná ospravedlnění je tak možné posoudit a vyhodnotit vzhledem k tomu, zda jejich nárok na platnost mohou obecně sdílet a potvrdit také druzí. Není-li podmínka recipročního a všeobecného ospravedlnění

2 Srv. B. Wolthuis - E. Mak - L. ten Haaf, Introduction, in: Netherlands Journal of Legal Philosophy, 3, 2016, str. 3-6.

3 Viz R. Forst, Ospravedlnění základních práv. Diskursivně-teoretický přistup, přel. M. Patočka - R. Pech, str. 135-163 v tomto čísle časopisu.

4 R. Forst, Das Recht auf Rechtfertigung. Elemente einer konstruktivistischen Theorie der Gerechtigkeit, Frankfur a. M. 2007, str. 25.

5 Tamt., str. 26-29. 
určitého jednání dodržena, pak není dodržena ani základní podmínka spravedlnosti. ${ }^{6}$

Protože teorii spravedlnosti Forst zakládá na teorii rozumového ospravedlnění obecně platných a závazných norem lidského jednání, buduje ji na základě diskursivní analýzy existujících diskusí a debat, které se týkají ospravedlnění určitého jednání, jež se uskutečňuje ve vztahu k obecně platným a závazným morálním, etickým, právním, politickým či společenským normám. Předmětem Forstovy diskursivní analýzy jsou proto i diskuse a debaty týkající se lidských práv. Tyto diskuse, debaty a spory podle Forsta historicky vycházejí z politických a společenských bojů; jsou výsledkem problematizace a delegitimizace zavedených politických a společenských pořádků. Vznikají tam, kde se lidé dožadují důvodů, které by ospravedlnily existující status quo, ale kde odpovědi, kterých se jim dostává, již nestačíi ${ }^{7} \mathrm{~V}$ takovém případě lidé podle Forsta zpravidla docházejí k názoru, že se s nimi jedná nespravedlivě; zkušenost nespravedlnosti se pak stává východiskem úsilí o společenské a politické změny, které na sebe může vzít a historicky také bere podobu boje za lidská práva, jehož normativním základem je idea lidské důstojnosti, svobody a autonomie.

Ideu lidské důstojnosti, svobody a autonomie lze s Forstem chápat jako normativní důvody, kterých lidé v dialogu a diskusi s druhými užívají k tomu, aby s jejich pomocí ospravedlnili úsilí o změnu svého společenského, politického, právního či ekonomického postavení. Lidská práva proto ve Forstově pojetí nejsou ani přirozená, ani vrozená, ale vytvořená: jedná se o specifický diskursivní konstrukt, který je v př́ípadě potřeby možno použít jakožto „emancipační nástroj“ generující odpovídající diskursivní a „normativní moc“. Pokud jsou ale lidská práva emancipačními a normativními prostředky, kterých se užívá k diskursivní legitimizaci, resp. problematizaci a delegitimizaci určitého jednání, předpokladem a podmínkou jejich diskursivního použití je na jedné straně právo, na druhé straně povinnost $\mathrm{v}$ případě potřeby žádat nebo poskytnout k ospravedlnění daného jednání takové důvody, které splňují

6 K principům reciprocity a všeobecnosti Forst odkazuje opakovaně, a to ve všech svých pracích. Jedná se tedy o určitý argumentační topos, který Forst užívá a uplatňuje v různých souvislostech a kontextech své politické filosofie. V základě se však všechny odkazy a užití přímo či nepř́ímo vztahují k Forstově teorii spravedlnosti a rozumového ospravedlnění. Srv. např. R. Forst, Toleranz, Gerechtigkeit, Vernunft, in: týž (vyd.), Toleranz. Philosophische Grundlagen und gesellschaftliche Praxis einer umstrittenen Tugend, Frankfurt a. M. 2000, str. 119-143.

7 Týž, Das Recht auf Rechtfertigung, str. 299-302. 
podmínku reciprocity a všeobecnosti. Normativním jádrem koncepce lidských práv, jejichž výčet se historicky různě vyvíjí a mění, je tedy podle Forsta základní právo na ospravedlnění, které náleží každému člověku jako člověku - jako bytosti nadané rozumem. ${ }^{8}$

I když se tedy Forst v souvislosti s problematikou lidských práv odklání od tradice přirozeného práva a přiklání $\mathrm{k}$ tradici právního konstruktivismu, jeho pojetí lidských práv zůstává universalistické. Universální platnost lidských práv u něho již ale nemá ani objektivní, ani subjektivní, nýbrž intersubjektivní základ: zakládá se v diskursivní praxi recipročního a všeobecného rozumového ospravedlnění lidského jednání. O tom, co takové pojetí předpokládá a vyžaduje, se Forst vyjádřil zcela výslovně: „rekonstruovat proces rozumového ospravedlnění jako intersubjektivní a tím takříkajíc postavit Kanta z transcendentální hlavy na sociální nohy“. ${ }^{9}$ Forstovu politickou filosofii, jeho teorii spravedlnosti, rozumového ospravedlnění i lidských práv lze tedy chápat jako pokus o reinterpretaci a překonání Kantovy transcendentální a kritické filosofie. Český překlad textu Ospravedlnění základních práv, ve kterém Forst své pojetí lidských práv, rozumového ospravedlnění a spravedlnosti shrnuje, proto českým čtenářum neprostředkuje pouze setkání s jedním z nejvýznamnějších myslitelů současnosti, ale také s jedním z nejvýznamnějších myslitelů minulosti. Kde končí minulost a začíná současnost, bude zde ovšem těžké rozhodnout. ${ }^{10}$

Robin Pech

8 Viz R. Forst, Kontexte der Gerechtigkeit. Politische Philosophie jenseits von Liberalismus und Kommuntarismus, Frankfurt a. M. 1994, str. 131-142, nebo týž, Das Recht auf Rechtfertigung, str. 33-36, 86-90 aj.

9 Týž, Das Recht auf Rechtfertigung, str. 81.

10 Tento text vznikl s podporou projektu GA ČR 19-07384S, Překonání dualismu mysli a hmoty v novověkém myšlení, řešeného na Filozofické fakultě Univerzity Karlovy. 